\title{
Puritanisme en Skotland
}

J W Claasen

Abstract

Puritanism and Scotland

Puritanism influenced the church in England, but had a more profound and lasting effect on religion in Scotland. In the process the Scottish church made some gains - the stress of the centrality of Scripture and preaching, the emphasis on true piety and pure life, the quest for renewal and the constant awareness of God's providence. The church also suffered losses - a preoccupation with subjective sanctification and selfexamination, the emergence of a scholastic federal theology, the overstress of the imperative, a subtle kind of legalism and an impoverished view of the sacraments. Scottish clergymen who came to South Africa during the nineteenth century can be associated with the evangelical faction of Scottish puritanism.

Die Puritanisme het nie alleen die kerk in Engeland beïnvloed nie, maar sedert die sewentiende eeu 'n rigtinggewende rol in die Skotse godsdienstige lewe begin speel. Voordat op spesifieke puriteinse invloede in Skotland ingegaan word, is 'n ondersoek van die historiese agtergronde en 'n begripsomskrywing noodsaaklik.

In 1553 het Mary Tudor (Bloody Mary) die Engelse troon bestyg. Haar vurige ywer om die protestantisme met Rooms-katolisisme te vervang, het 'n hewige vervolging van protestante tot gevolg gehad. Baie mense het na die Europese vasteland gevlug. In Geneve het 'n groot groep vlugtelinge 'n ballingskapsgemeente gevorm en die gees van die Calvinistiese protestantisme ingeadem. Mary Tudor se dood in 1558 het 'n einde aan die vervolging gebring. Haar opvolger Elizabeth I het die anglikaanse episkopaat weer herstel'.

Vlugtelinge het mettertyd met "a thoroughgoing Protestantism" na Brittanje teruggekeer ${ }^{2}$. Hulle was gou onvergenoegd met baie anglikaanse gebruike wat vir hulle al te veel na Rome oorgeleun het ${ }^{3}$. Dié beswaardes het die suiwer (pure)-ing van die Anglikaanse Kerk bepleit en was spoedig as puritans bekend ${ }^{4}$. Hulle was gekant teen voorgeskrewe drag vir geestelikes. Volgens hulle was dit 'n bedreiging vir die amp van die gelowige, daar dié drag die gedagte van spesiale kragte by die leek ontlok het. Die knielende ontvangs van die nagmaalselemente het hulle afgekeur, omdat dit ' $n$ "adoration of the physical presence of Christ therein"5 sou voorstel. Hulle het die gebruik van die ring in die huwelik veroordeel as 'n voortsetting van die huwelik as 'n sakrament. Die kruis by die doop was vir hulle 'n teken van bygeloof'.

Die benaming puritein is en word dikwels misbruik 7 . Tereg sê Collinson: "Puritanism was in the eye of the beholder"8. Soms is die naam as 'n wapen "of sophisticated stigmatisation" aangewend". Volgens Packer het die benaming sedert die 1560 's in die modder beland: "It was always a satirical smear word implying peevishness, censoriousness, conceit, and a measure of hypocrisy...its primary reference...was seen as an odd, furious, and ugly form of Protestant religion"10. 'n Verandering het weliswaar in die afgelope vyf dekades ingetree. "Scholars have been meticulously wiping away the mud. And as Michelangelo's frescoes in the 
Sistine Chapel have unfamiliar colors today now that restorers have removed the dark varnish, so the conventional image of the Puritans has been radically revamped, at least for those in the know"11. Hall meen dat die naam te algemeen gekoppel word aan almal "who struggled against Anglicanism...as a homogeneous group"12.

Van Schelven kritiseer die benaming as "een naam zonder vaste betekenis"13, aangesien dit "zowel de Presbyterianen als de Independenten"14 kan aandui. Dickens reken dat, indien ons die ware karakter van puritanisme wil vasstel, ons denke van die populêre gebruik van dié begrip bevry moet word. Hierdie gebruik het sy oorsprong in die satire wat teen Victoriaanse godsdienstige skynheiligheid van die negentiende eeu gemik was ${ }^{15}$. Puritanisme is tog veel meer as net 'n oppervlakkige obsessie met seks en plesier. Die teologiese onderbou daarvan is baie meer gekompliseerd.

Van den Berg kenskets puritanisme soos volg: "that movement which longed to give the church a more 'pure' character, modelled on the Biblical ideal which they saw embodied especially in Geneva. All of life was to be reformed according to the Word of God, and it was especially from Calvin that they had learned this". Van den Berg gee toe dat sekere puriteinse groepe wel van die reformatoriese Calvinisme afgewyk het ${ }^{16}$. Die hoofstroom "daarentegen wilden zich geheel aan Calvijn oriënteren. De invloed van Calvijn is in het Puritanisme en in de puriteinse ethiek fundamenteel"17. Volgens Sprunger is die essensie van puritanisme 'n ewewigtige kombinasie van Calvinistiese teologie en intense persoonlike vroomheid 18 .

William Ames vat die puritanisme in drie stellings saam: Hulle het 'n purified kerk begeer, "they strive for personal and public righteousness (meaning, a reform of manners and morals, Sabbath observance, prayers, good conversation, and the shunning of stage plays, swearing, drunkenness, masking, dicing, and all sorts of reveling)"19 en hul vertrekpunt en rigsnoer was God se Woord. In hul poging om die kerk te suiwer en godsvrug te bevorder, het puriteine aan die sola scripturabeginsel vasgehou ${ }^{20}$. Elke lewensfaset moes die toets van die Skrif deurstaan, "moreover, the Bible gives infallible directions for every area of life"21.

Puriteine het groot nadruk op 'n vroom en persoonlike godsdiensbelewing gele22. Die oortuiging van sonde, 'n oproep tot bekering en toewyding, en die ervaring van vergifnis was belangrike kenmerke van hul prediking 23 . Hulle het 'n "concern for authentic religious experience" 24 gehad. Lloyd-Jones sê dat die puriteine se "primary interest was pastoral and experiental in a personal sense. That was their genius; and it was this that fitted them for the peculiar work they were called upon to do - the analysis of cases of conscience, the resolution of doubts and helping people who were in trouble"25. 'n Eksperimentele selfondersoek was 'n integrale deel van die deursnee puriteinse godsdiensbelewing ${ }^{26}$.

Breward beskryf die puriteinse selfondersoek soos volg: "Every aspect of life had to be scrutinized by constant self-examination, so that the temptations to sin were hated as sin itself"27. Deur meditasie het die puritein daarna gestreef "to search and challenge his heart, to stir his affections to hate sin and love righteousness" 28 . Torrance bemerk 'n negatiewe ontwikkeling in dié puriteinse selfondersoek: "A major preoccupation of the Puritans becomes therefore increasingly that of subjective sanctification and self-examination with a self-concious concern to live according to biblical precedents and principles, with a constant pastoral concern for 
cases of conscience"29. Daar moet toegegee word dat die puriteinse klem op persoonlike vroomheid soms tot twee uiterstes gevoer is - 'n legalistiese lewenswandel en die oorbeklemtoning van die indiwidu se persoonlike beslissing in bekering ${ }^{30}$. Veral eersgenoemde afwyking het in die Skotse godsdiensbelewing voorgekom.

Die puriteinse erediensinrigting het van barre eenvoud getuig 31 . Die preek wat die hoogtepunt was, was meestal eenvoudig in styl, baie op die affektiewe ingestem ${ }^{32}$ en deur 'n retoriese oorredingsappél gekenmerk. Die hoorder moes beweeg word om reg voor God te lewe. "The aim of the application was to stir the individual Christian to a change of behaviour wherever it was needed by awakening the conscience. For the Puritans, preaching was a subversive activity" ${ }^{13}$.

In baie puriteinse geskrifte word die bevordering van die koninkryk van God deur middel van herlewings benadruk ${ }^{34}$. "The kingdom of Christ would spread and triumph through the powerful operations of the Holy Spirit poured out upon the Church in revivals"35. Packer verklaar dat die puritanisme inderwaarheid "a movement of spiritual revival" 36 was. Puriteine het die term revival nie gebruik nie, "but expressed their objectives entirely in terms of the vocabulary of "reform'"37. Vernuwing geskied nie deur die omverwerping van die bestaande nie, maar "at the congregational level coming in disciplined style through faithful preaching, catechizing, and spiritual service on the pastor's part" 38 .

In hul toekomsvisie was puriteine geen fataliste nie. God is vertrou dat hy deur sy Gees nuwe lewe vir die kerk en die indiwidu sou bring39. Baie puriteine het geglo dat die Skrif wêreldwye sukses vir die evangelie voorspel, dit deur die herhaaldelike uitstorting van die Heilige Gees sou realiseer, die kerk die instrument daartoe sou wees en dit die antwoord op volhardende gebed sou wees. Daar is 'n noue verband tussen die puritanisme en die herlewings van die agtiende en negentiende eeue in Brittanje en Amerika 40 . "Revivalism, on its part, was the heir of Puritanism's emphasis on the new birth, and on sanctification, but revivalism lacked Puritanism's rational self-discipline"41. Packer maak 'n belangwekkende waarneming: "Further light on the Puritan revival would come from a study of Puritan theology, in particular its unprecedented interest in, and concentration on the ministry of the Holy Spirit; and also from a review of Puritan worship, with its stress on 'heart-work', spontaneity, the singing of hymns and psalms, free Spirit-prompted prayer marked by 'familiarity', 'fulness' and 'affection', and the 'plain, pressing, downright' preaching of sin and grace which would 'rip up' the conscience and then pour in gospel balm. Puritan theology and worship, as they developed, showed increasingly their character as both products and adjuncts of revival" 42 .

'n Holistiese benadering van die lewe het die puriteine gekenmerk. "All creation, so far as they were concerned, was sacred, and all activities, of whatever kind, must be sanctified, that is, done to the glory of God"43. Die puriteine het groot waarde aan die voorsienigheid van God geheg. Hulle het God se aktiewe betrokkenheid in elke dag se gebeure raakgesien. "They confidently expected to find God in the milkhouse, the stable, the barn, and the like, where God (visits) the soul"44. God se algemene en spesifieke voorsienigheid figureer prominent in die puriteinse literatuur. In die puriteinse geskiedenisbeskouing gebeur niks sonder God nie ${ }^{45}$. "It was also a view that saw the entire course of human history, from the most personal and private griefs to the most general national and international crises, as direct emanations of the divine will"46. Terugslae bring die gelowige opnuut onder die besef van sy onmag en sonde en laat hom na God teruggryp ${ }^{47}$. Die goddelose 
ervaar God se mag nie geestelik nie, maar is slegs bekommerd oor sy tydelike voortbestaan ${ }^{48}$. 'n Sterk morele bewustheid het hom meester van die puriteine gemaak. Die vraag na reg of verkeerd was 'n kardinale lewensvraag. Die lewe is as 'n voortdurende stryd tussen die goeie en die bose ervaar. "The world was claimed by God and counterclaimed by Satan. There was no neutral ground"49.

Oor kerkregering het puriteine onderling verskil. In navolging van Calvyn was een groep, naamlik die presbiteriaanse puriteine, ten gunste van die presbiteriale stelsel 50 . 'n Tweede faksie was baie pessimisties oor pogings om die Anglikaanse Kerk kerkregtelik te hervorm. Sommige het gereken dat dit "entirely hopeless" 51 sou wees en het weggebreek van die Anglikaanse Kerk. Hulle was die separatists of dissenters. Vir hulle was die kongregasionalistiese stelsel die aangewese vorm van kerkregering 52 .

Elizabeth I was onwillig om die Anglikaanse Kerk in puriteinse bane te stuur 53 . Haar kerklike hervormings het die puriteine nie tevrede gestel nie ${ }^{54}$. Thomas Cartwright en sy ondersteuners wou egter nie die Anglikaanse Kerk verlaat nie. 'n Ander puritein Robert Browne het wel weggebreek en in 1581 'n eie independente gemeente gestig55. Die presbiteriane in Skotland se simpatie was by Cartwright se faksie ${ }^{56}$. Cartwright is selfs 'n professoraat in Skotland aangebied ${ }^{57}$.

Die Skotse kerklike lewe het spoedig binne die direkte invloedsfeer van die Engelse presbiteriaanse puritanisme gekom ${ }^{58}$. Andrew Melville(1545-1622), John Knox se opvolger, was 'n goeie vriend van twee vooraanstaande Engelse puriteine - Cartwright en Walter Travers ${ }^{59}$. Kerkhistorici verbind Knox met die Engelse puritanisme ${ }^{60}$. Hume Brown noem Knox "the founder of Puritanism in England"61. Knox het 'n simpatieke oor vir die saak van die Engelse puriteine gehad62. William Kethe, een van Knox se lojale ondersteuners en oud-lidmaat van sy gemeente in Frankfurt, word later die "greatest songwriter of the Puritan movement" 63 en talle van sy komposisies het deel geword van die liedereskat van die Skotse kerk. Knox het hoë aansien by Engelse puriteine geniet en Skotland was meermale ' $n$ toevlugsoord vir Engelse puriteine "wherein they could experience that discipline they craved for England"64. Puriteinse werke soos The Pilgrim's Progress van Bunyan en Baxter se The Saints' Everlasting Rest was gewild in Skotland65. Skotse presbiteriane en Engelse puriteine was in dieselfde bootjie - 'n gemeenskaplike teenstander: episkopalisme 66 .

Die puritanisme was die manifestasie van 'n opregte bekommernis oor die verwording van die episkopalisme in Engeland en Skotland ${ }^{67}$. Puriteine wou God se Woord weer sentraal plaas en hul kommer oor morele agteruitgang was nie ongegrond nie ${ }^{68}$. Ongelukkig het hulle soms verswelg geraak in 'n wettiese "geest van precisiteit"69. 'n Verenging en verharding in die puriteinse visie tree veral na 1660 in ${ }^{70}$. Die siening van sabbatsheiliging getuig hiervan ${ }^{71}$.

Nougesette sabbatsheiliging het sedert die sewentiende eeu die Engelse en Skotse gemeenskapslewe gekenmerk: "For Puritans, Sabbatarianism was not merely one doctrine among many - take it or leave it - but the essential social teaching"72. Alhoewel sabbatarianisme nie tot Engeland en Skotland beperk was nie, was dié twee lande die enigste wat "the full apparatus of Sabbatarianism"73 ontwikkel en verfyn het. Selfs nie eers Calvyn se beklemtoning van die sabbat was daarmee vergelykbaar nie: "No reputable theologian.....went as far as the Puritans; no other churches in the world practiced the Puritan Sabbath"74. God se dag was 'n dag van aanbidding en rus. Winkels moes sluit en slegs werke van absolute nood- 
saak is toegelaat. Ontspanning en sport op dié dag was ondenkbaar. Hierdie sabbatsbeskouing het ook sosiale, politieke en ekonomiese implikasies gehad. Sabbatarianisme was God se wil vir elke mens. Gedurende die sewentiende eeu het die Britse owerhede baie bepalings in dié verband op die wetboek geplaas ${ }^{75}$. Kerkrade het min simpatie met sabbatskenders gehad. Barbiers en bierbrouers was veral in Skotland die sondebokke 76 . Die Sondag het vir baie 'n dag van "gloom, restraint and oppression"77 geword.

Skotland was in 'n sekere sin ryp vir die invloede van puritanisme: "The Scottish temperament, though deep and sensitive, is somewhat angular and controversial, and this is apt to produce, unless counteracted, a more or less gloomy and morose attitude to life...It is therefore not unnatural that Scotland provided a fruitful soil for the spirit of Puritanism...Puritanism captured the Scottish Church and religious life"78. Flynn sien die invloed van puritanisme in Skotland ${ }^{79}$ egter in 'n positiewe lig. Puritanisme kry die krediet vir die bekering van die wilde hooglandse clans en "the admirable spirit of independence in politics". Skotland was in die dae van Knox 'n agterlike en armoedige land. Die puritanisme het gesorg vir "wealth and intelligence"80. Ongelukkig was daar ook negatiewe gevolge.

In die stryd teen episkopaalse invloede het die Skotse presbiteriane soms oorgereageer: "But out of the presbyterian opposition to these things came the puritan developments in worship - the rejection of all read prayers as impiety, the relegating of the devotional part of the service to the inferior place of mere preliminaries to the sermon, and that order of communion, where, at the changing of the tables, those who have communicated crush out and those who are about to communicate crush in, and there is inevitable jostling, all to the accompaniment of the 103rd Psalm"81. Puriteinse invloede het dikwels tot die verarming van en 'n verstarring in die Skotse erediens gelei82. "Puritanism, however, to a great degree drove from life its colour and its charm, and nowhere did this hit Scotland with greater severity than in the public worship of its Church. This, sincerely directed at first towards simplicity, and a search for pure spiritual reality, soon fell away from its high idealism and slithered down into a stagnant morass of ineptness and neglect" 83 .

Rigiede puriteinse dissipline het die kerklike tug meermale laat ontaard: "Following Calvin's anxiety for a Christian way of living they overlooked his concern for inwardness and genuineness, and so were content to demand outward observance like any Pharisee or Romanist...Thus session minutes ${ }^{84}$ from the end of the sixteenth century to the middle of the eighteenth record many offences under the head of Sabbath-breaking, including drinking in time of sermon, playing golf, fishing, buying and selling, travelling, quarrelling, smuggling, shooting pigeons, carrying in water, killing a sheep ${ }^{85}$." Volgens Henderson het die Skotse kerk in 'n sekere mate fariseisties begin word. In die tuguitoefening is te veel op die vleeslike gekonsentreer, terwyl "more deadly faults such as pride, hypocrisy and the want of charity" 86 uit die oog verloor is. James Philip noem dit geestelike arteriosklerose ${ }^{87}$. Provand reken dat Melville "sowed the seed which grew and multiplied into the dismal harvest of ultra-protestant puritanism"88. Yule is baie skerp in sy kritiek: "Melvillian Presbyterianism and English Puritanism also deviated from the Reformation and also became moralistic and in the last analysis Arminian, in a subtle kind of way, because, moving from the christological centre of Luther and Calvin, faith became a type of work and more emphasis was placed on the right response of one's faith than on the source of grace - Jesus Christ. This change is due to a 
hermeneutical change to a far greater degree than is normally recognised. The Bible as precedent displaced the sola gratia as the centre of theological attention $89 . "$

Puritanisme het ook die alledaagse lewe ingrypend geraak: "Hence, by way of protest, the puritan view that a sad countenance is a sign of piety, and that recreation is almost sinful, hence the speaking of cards as the 'devil's picture books', and the ban of the Church on music and dancing"90. Provand beskryf die lewensuitkyk van baie Skotse lidmate op treffende wyse: "At first it was the ministers who were expected to display a preternatural solemnity, and if they wished a reputation for sanctity, never to be seen to smile, but to mingle sighs and groans with their conversation; but the well-known tendency for men to lay on others the same burdens which they have chosen for themselves soon prevailed, and all who professed to be the Lord's people were expected to show those marks of grace"91.

Die verbondsteologie is ' $n$ inherente en belangrike aksent in die puritanisme. Om die Skotse puritanisme werklik te begryp, is dit gebiedend noodsaaklik dat daar na die covenant-teologie gekyk word. Reeds in 1557 het 'n aantal Skotse adellikes 'n verbond gesluit waarin hulle onderneem het "to establish the most blessed Word of God and his congregation"92. Dit was die "First Scottish Covenant ${ }^{93 . " ~ O n d e r ~ d i e ~ b e s k e r m i n g ~ v a n ~ h i e r d i e ~ c o v e n a n t ~ i s ~ p r o t e s t a n t s e ~ g e b r u i k e ~}$ openlik in die Skotse kerk ingevoer ${ }^{94}$. In 1638 is die National Covenant gesluit ${ }^{95}$. Die Solemn League and Covenant tussen Skotland en Engeland 96 volg in 1643. Beide covenants was gemik teen episkopalisme en deur talle Skotte feitlik as fetisje beskou97. Ongeveer 300000 mense het die Solemn League and Covenant onderteken ${ }^{98}$. Behalwe persoonlike covenants, vertel die Skotse geskiedenis tussen 15561683 van nie minder nie as 31 "public bands and covenants" 99 . Die covenanters het Skotland gedurende die sewentiende eeu selfs vir 'n tyd regeer en ook 'n eie leër $\operatorname{gehad}^{100}$.

Watter teologiese uitgangspunte lê die Skotse covenant-beweging ten grondslag? Torrance voer die verbondsteologie in Brittanje terug tot die Engelse puritanisme. Engelse verbondsteoloë soos die puritein William Perkins (1558-1602) het ' $n$ beduidende invloed op die teologiese denke in Skotland en Engeland gehad. Deur Robert Rollock (1555-1599) se toedoen het die verbondsteologie spoedig in Skotland wortel geskiet ${ }^{101}$. Hy het die begrip covenant of works gebruik en geglo dat God met die mens alleenlik deur 'n covenant handel. In die covenant of works het Christus geen plek nie. Die evangelieboodskap begin met "the legal doctrine of works and of the law...if this preparationist ordo is not followed then the preaching and the promises of the gospel are in vain"102. Rollock het 'n verskuiwing in Skotse teologiese denke ingelui - van die tintelende evangeliese teologie van Calvyn na die meer skolastiese benadering van die verbondsteoloë ${ }^{103}$. In Rollock se spore het teoloë soos Samuel Rutherford en David Dickson gevolg104. Dié twee het selfs drie covenants onderskei: die covenant of works (God en Adam), die covenant of redemption (God en Adam), en die covenant of grace (God en mens in Christus) ${ }^{105}$. Nederlandse verbondsteoloë soos Voetius, Witsius, Marckius en veral Coccejus het later 'n invloed in Skotland gehad106. Die verbondsteologie van die Westminster Confession het verdere stukrag aan die covenant-beweging verleen. Sedert 1647 het die Westminster Confession 'n prominente plek in die Skotse teologie en kerk beklee en het dit reeds vir meer as drie eeue behou. By die Westminster Assembly se eerste sitting wat in Julie 1643 plaasgevind het ${ }^{107}$, was presbiteriaanse puriteine by verre in die meerderheid ${ }^{108}$. Dié byeenkoms het verskeie belangrike dokumente opgestel en 
goedgekeur waarvan die Confession of Faith seker die bekendste is ${ }^{109}$. Die Westminster Assembly het minder invloed in Engeland uitgeoefen ${ }^{110}$, veral omdat die Assembly-besluite taamlik halfhartig deur die Engelse parlement toegepas is ${ }^{111}$. Daarby het Cromwell 'n einde aan die politieke mag van die presbiteriaanse puriteine gebring112. In Skotland was dit egter 'n perd van 'n ander kleur: "The Scottish General Assembly, in high hope and expectation of one Presbyterian Church in the British Isles, had already hastened to lay aside its Knoxian Liturgy and Creed in favour of the new Westminster standards, and continued to adhere to them even after the English collapse"113.

Die verbondsteologie figureer duidelik in die teologiese premisse van die Westminster Confession ${ }^{114}$. Die uitgangspunte van Perkins, die puriteinse verbondsteoloog het ' $n$ wesenlike invloed op die meerderheid afgevaardigdes na die Westminster Assembly gehad ${ }^{115}$. Deur die Confession het die presbiteriaanse puritanisme dus steeds 'n belangrike invloed op die Skotse kerk en in die besonder op die covenanters uitgeoefen: "Scotland was permanently affected, for it received as its standards of doctrine, worship, and government the principal documents issued by this assembly, including Westminster Confession, Larger Catechism, Shorter Catechism, Directory for the public worship of God, Form of Presbyterial Church Government, and a new version of the Metrical Psalms. These were all largely the work of English Puritans...there can be no doubt that in this period English Puritanism considerably influenced the Scottish Church"116.

Kendall wil in sy omstrede Calvin and English Calvinism to 1649 'n saak daarvoor uitmaak dat die puriteinse teologie en die Westminster Confession as eksponent daarvan, ernstig van die tradisionele Calvinisme afgewyk het. Volgens hom het Theodore Beza en nie Calvyn nie, die puriteinse teologie fundamenteel beinvloed: "The architectural mind of Westminster theology, however, is Beza. Limiting the death of Christ to the elect robbed reformed theology of the simple idea that Christ alone is the mirror of election, hence the ground of assurance. Beza, moreover, was the first to use language that virtually made faith a condition that binds God to the promise; the voluntarism of reformed theology centred on this concept, and things were never the same again. This voluntaristic seed grew into what we now know as federal theology"117. Kendall se siening kom daarop neer dat die puriteinse geloofsleer Arminiaans ${ }^{118}$ was. Syns insiens het die puriteine Calvyn se ordo salutis van "faith and repentance"119 omgeruil.

Yule, Torrance en Bell argumenteer soos Kendall dat die Westminster Confession nie so suiwer Calvinisties is as wat algemeen aanvaar word nie. Hulle sien 'n duidelike verband tussen die covenant-teologie en die teologie van die Westminster Confession. Beide was eksponente van die verbondsteologie ${ }^{120}$. Yule toon aan dat die dualiteit van covenant of works en covenant of grace wat ons by die covenanters teëkom, ook aanwesig is in die Westminster Confession. "The doctrine of creation is divorced from redemption. But for Calvin there is one covenant, and that of grace, for redemption is no mere after-thought on the part of God. Again for the Reformers, with their insistence on the centrality of sola gratia, union with Christ is the heart of the Gospel, but the Westminster theology insists first on the judicial justification and justifying faith before we can enter into union with Christ. This makes the forensic and believing elements more important than grace"121.

Helm argumenteer in sy Calvin and the Calvinists dat die verskille tussen Calvyn en die puriteinse teologie nie oorbeklemtoon behoort te word nie ${ }^{122}$. $\mathrm{Hy}$ 
verwerp Kendall se analise en kom tot die slotsom dat Calvyn en die puriteine in hul uiteensetting van tradisionele gereformeerde geloofswaarhede wesenlik ooreenstem ${ }^{123}$. Helm konkludeer verder: "There are, of course, theological differences between John Calvin and later Calvinism, for example the explicit doctrine of limited atonement, covenant theology, and the careful discrimination between faith and assurance. But the differences on such matters in Reformed theology during the period under discussion are more sensibly to be accounted for in terms of a live developing theological tradition meeting new problems such as Arminianism and post-Tridentine Roman Catholicism, and by individual differences in temperament, culture and pastoral situation"124.

Gedurende die laaste dekade of wat het daar belangrike artikels en publikasies oor die stand van die Skotse teologie tydens die sewentiende eeu verskyn. J $B$ Torrance en C Bell ${ }^{125}$ is veral hiervoor verantwoordelik. Terwyl ons die twee geleerdes se analise van die Skotse teologie onder die loep neem, moet ons in gedagte hou dat beide geesgenote van Kendall is 126 . In die bespreking wat volg, konsentreer ons veral op uitsprake van Torrance en Bell.

Soos voorheen gemeld, mak die covenant-teologie 'n duidelike onderskeid tussen die foedus naturae aut operum en die foedus gratiae. God het met Adam 'n werksverbond gesluit waarby alle mense ingesluit is. In die werksverbond is God die "contracting sovereign, law giver and judge. But only the elect are related to God by grace, for God has made a second covenant for them in Christ"127. Volgens Torrance het die woord covenant in Skotland nie die betekenis van 'n unconditional covenant gehad nie, maar veel eerder dié van 'n voorwaardelike kontrak. Dié afwyking van die Calvinistiese verbondsopvatting het tot gevolg gehad dat die Skotse godsdiensbelewing in die sewentiende eeu meermale ' $n$ wettiese vorm begin aanneem het ${ }^{128}$. Hierdie kontraktuele siening van God se verhouding met die mens het uiters nadelig op die Skotse godsdiensbelewing ingewerk en gelei tot die ontwrigting van die Skotse teologie vir' $n$ baie lang tyd.

Dit het verreikende implikasies vir die prediking, sakramentsbeskouing en aanbidding gehad: "During the seventeenth century, a change began to take place in Scottish preaching where a subtle kind of legalism began to creep in. The Scottish preacher preached the law in such a way that his concern was to produce a conviction of sin and a fear of judgement, so that he could call upon the sinner to repent and renounce his sin so that he might receive the word of forgiveness and hear the comforts of the Gospel"129. Henderson noem die covenant-periode "theological unrest"130. Die prediking het so gekonsentreer op sonde, oordeel en selfondersoek dat "the notes of joy and peace and gratitude and praise for the forgiveness so freely given in Christ"131 op die agtergrond geskuif is. Die klem het in plaas van op die indikatief nou op die imperatief geval132.

Hierdie uitgangspunt het ook neerslag gevind in die Skotse sakramentsbeskouing. Die nagmaal is in 'n kontraktuele verband gesien en dit het gelei tot die sogenaamde fencing of the table $e^{133}$. Torrance konkludeer: "Is this not precisely what we have witnessed in Scotland? Is there not the real danger here of turning the Sacrament of the Lord's Supper into a sacrament of penance by making forgiveness and the benefits of redemption conditional on repentance and conversion and some great act of renunciation"134. In talle Skotse gemeentes het net 'n handjievol lidmate nagmaal gebruik ${ }^{135}$. Volgens Kirk het die uitverkiesingsleer ook 'n klemverskuiwing ondergaan: "Yet covenant or federal theology, if carried to the 
extremes, could undermine the doctrine of predestination. It ultimately shifted the emphasis in Calvinism away from the eternal decree of God by focusing attention on the reciprocal obligations of the contract between man and God"136.

Dit is ook van belang om op die Skrifbeskouing van die covenanters te let. Alles is verwerp wat nie uitdruklik in die Bybel uitgespel was nie ${ }^{137}$. Die Ou Testament was baie belangrik ${ }^{138}$. Die Bybelse doodstraf vir owerspel, towery, die vloek van vader of moeder, afgodedienaars en lasteraars het steeds gegeld, want God verander nooit en dus ook nie sy verordeninge nie ${ }^{139}$ : "It was in the Hebrew Sciptures that the Covenanters found their Sabbath and their fast day, their covenant and their intolerance"140. Die covenanters het die Tien Gebooie beskou as 'n "re-publication of the law of nature and the law of nature (including the law of the Sabbath) is the foundation of society and for the State consequently to violate the law of nature is to expose society to divine judgment"141.

Sekerheid van geloof het ook in die slag gebly. Rollock definieer geloof as "an intellectual assent to knowledge, and he gives it an active sense by making it more a matter of man's will...he lays great stress on our sense perception of assurance and speaks of faith as a feeling of God's grace. He then turns us inward to discern the effects of santification to make our election sure, thus removing the objective base of certainty from the finished work of God in Christ, and leaving us with the uncertainty of our sense perception"142. Die objektiewe basis van geloofsekerheid is vervang met die subjektiewe wisselvalligheid van die gelowige se emosies ${ }^{143}$. Die opvatting dat God se covenant 'n kontrak is, bring 'n ommeswaai in die ordo salutis teweeg. Volgens Torrance is die gevolg daarvan dat "we hesitate in the name of Christ to proclaim absolution and free forgiveness of sins, or hesitate to believe that we are forgiven. So the Scottish mind has too often been torn by the question of assurance"144.

Kendall, Torrance en Bell se kritiek op die Skotse puritanisme is myns insiens te skerp, soms op verkeerde voorveronderstellings gebaseer en belas met 'n geforseerde skematisme. Tog is dit duidelik dat die puritanisme in sekere fasette van die Skotse kerklike en godsdienstige lewe 'n verskuiwing weg van Calvyn veroorsaak het. Ons mag egter nie die positiewe bydrae vergeet nie - die sentrale plek van die Woord (prediking), die noodsaak van ware godsvrug en vernuwing asook die teosentriese geskiedenisbeskouing. Die bestudering van die puritanisme in Skotland is ook vir ons in Suid-Afrika van belang, aangesien die Skotse leraars wat gedurende die vorige eeu na ons land toe gekom het, verbind kan word met die evangelical-faksie van Skotse puritanisme ${ }^{145}$.

\section{NOTAS:}

1 W Walker, $A$ history of the christian church, Edinburgh ${ }^{4} 1986,492-495$.

2 Walker, $a w, 543$.

3 Vergelyk J L Ainslie, "The Scottish Reformed Church and English Puritanism", Records of the Scottish Church History Society 8(1944), 75.

Ainslie, Records of the Scottish Church history society 8(1944), 75; Walker, a $w, 544$. Walker reken dat die naam teen die vroeg-1560's sy beslag gekry het. 
In J B Rogers se D Th-proefskrif, Scripture in the Westminster Confession. $A$ problem of historical interpretation for American Presbyterianism, Kampen 1966, 203 word gemeld dat Basil Hall meen dat die naam puritein nie voor 1563 gebruik is nie.

$5 \quad$ Walker, $a w, 544$.

$6 \quad$ Walker, $a$ w, 544.

7 Ryken noem verskeie misbruike van die woord puritein. Vergelyk L Ryken, Worldly saints. The Puritans as they really were, Grand Rapids 1986, 2-7.

8 P Collinson, "A comment: Concerning the name Puritan", The Joumal of Ecclesiastical History 26(1980), 487.

9 Collinson, The Journal of Ecclesiastical History 26(1980), 486. Volgens Rogers is die naam puritein soms geassosieer met ondersteuners van 'n ortodokse leer. Op sodanige wyse is Calvyn 'n puritein genoem, vergelyk Rogers, $a w, 210$.

10 Ryken, $a w$, ix.

11 Ryken, $a w$, ix-x. Volgens Packer was die deursnee puriteine nie wilde fanatici nie. Hulle was nie "fierce and freaky, religious fanatics and social extremists, but sober, conscientious, and cultured citizens, persons of principle, determined and disciplined, excelling in the domestic virtues, and with no obvious shortcomings save a tendency to run to words when saying anything important, whether to God or to man". (Ryken, $a w, x)$.

12 Rogers, $a w, 202$. Rogers haal hier aan uit 'n artikel van Basil Hall, "Puritanism: The problem of definition", Studies in Church History 2(1965), 283-296.

13 A A van Schelven, Het Calvinisme gedurende zijn bloeitijd: Zijn Uitbreiding en Cultuurhistoriese betekenis 2, Amsterdam 1943, 134.

14 Van Schelven, $a w$, 135. Packer identifiseer vyf verskillende groepe met wie hierdie benaming verbind kon word - "clergy who scrupled some Prayer Book ceremonies and phrasing....advocates of the presbyterian reform programme....clergy and laity, not necessarily nonconformists, who practised a serious Calvinistic piety....'rigid Calvinists' who applauded the Synod of Dort....MP's, JPs and other gentry who showed public respect for the things of God, the laws of England and the rights of subjects". J I Packer, "Puritanism as a movement of revival", The Evangelical Quarterly 52(1980), 2.

15 A G Dickens, The English reformation, New York 1964, 315-316.

16 Aangehaal deur Rogers, $a w, 213$. 
17 J van den Berg, "Het puriteinse ethos en zijn bronnen", Vox Theologica 34(1963-1964), 2. Vergelyk B K Kuiper, The church in history, Grand Rapids $111975,251$.

18 K L Sprunger, Dutch Puritanism. A history of English and Scottish churches of the Netherlands in the sixteenth and seventeenth centuries, Leiden 1982, 457. Hierdie is 'n uitstekende, wetenskaplike studie wat duidelike lyne tussen die Hollandse en die Britse kerke trek. Dit onderstreep die noodsaak om kerkgeskiedenis in 'n breë konteks te bestudeer.

19 Sprunger, $a w, 458$.

20 Ryken, $a w, 13,219$.

21 Sprunger, $a w, 459$.

22 Rogers, $a w, 244$.

23 Ryken, $a$ w, 14; O C Watkins, The Puritan experience, London 1972, 5-9.

$24 \mathrm{~J}$ B Torrance, Calvin and puritanism in England and Scotland, some basic concepts in the development of "federal theology", in B J van der Walt, Calvinus reformator. His contribution to theology, church and society, Potchefstroom $1982,277$.

25 D M Lloyd-Jones, The Puritans: Their origins and successors, Edinburgh 1987, 11.

26 Watkins, $a$ w, 9-12.

27 S B Ferguson \& D F Wright (eds), New Dictionary of Theology, Leicester $1988,552$.

28 Ryken, $a w$, xii.

29 Torrance, $a w, 276$.

30 Torrance, $a w, 276$.

31 Ryken, $a$ w, 119-123; W S Provand, Puritanism in the Scottish church, Paisley 1923, 207-210.

32 Ryken, $a w, 102-107,126$. Vergelyk P Collinson, $A$ mirror of Elizabethan Puritanism. The life and letters of "Godly Master Dering", London 1964, 8-11.

33 Ryken, $a w, 101$.

34 I H Murray, The Puritan hope, Edinburgh ${ }^{3} 1984,52$.

35 Murray, $a$ w, 51; vergelyk 241-255.

$36 \quad$ Packer, The Evangelical Quarterly 52(1980), 5. 
37 Packer, The Evangelical Quarterly 52(1980), 5; vergelyk Lloyd-Jones, a w, 10,348-349; Ryken, $a w$, xv.

$38 \quad$ Ryken, $a w$, xv.

39 Packer, The Evangelical Quarterly 52(1980), 6-10.

$40 \quad$ Murray, $a w, 51-52,90,99$.

41 Aangehaal deur J J de Klerk, Prediking, Pretoria 1977, 52. Ongelukkig dui De Klerk nie sy bron aan nie.

42 Packer, The Evangelical Quarterty 52(1980), 15-16.

43 Ryken, $a w$, xi-xii.

$44 \quad$ Ryken, $a w, 15$.

$45 \quad$ P Lake, Moderate Puritans and the Elizabethan Church, Cambridge 1982, 119120; D K McKim, "The Puritan View of History", The Evangelical Quarterly 52(1980), 215-237.

$46 \quad$ Lake, $a w, 122$.

$47 \quad$ Lake, $a w, 125,136$.

$48 \quad$ Lake, $a w, 125$.

49 Ryken, $a w, 11$.

50 Vergelyk R B Knox, "Puritanism past and present", Scottish Journal of Theology 19(1967), 296. Van Schelven verkies om eerder van AngloCalvinisme te praat. Van Schelven, $a w, 135$. Torrance het 'n voorkeur vir die term puriteinse Calvinisme. A I C Heron (ed), The Westminster Confession in the church today. Papers prepared for the Church of Scotland panel of doctrine, Edinburgh $31986,54$.

$51 \quad$ Kuiper, $a w, 251$.

$52 \quad$ Kuiper, $a w, 251$.

53 T Dowley (ed), The history of Christianity, Berkhamsted 1977, 388; Walker, $a$ w, 544 .

$54 \quad$ Walker, $a w, 544$.

$55 \quad$ Walker, $a w, 545-548$.

$56 \mathrm{~J}$ MacLeod, Scottish theology in relation to church history since the reformation, Edinburgh 21974, 35.

57 MacLeod, $a w, 35$. 
58 G D Henderson, The Church of Scotland. A short history, Edinburgh 1939, 71-72,91-92; J S Flynn, Influence of Puritanism on the political and religious thought of the English, London 1920, 91.

59 J Kirk, "The influence of Calvinism on the Scottish reformation", Records of the Scottish Church History Society 18(1974), 176.

60 H Jedin \& J Dolan (eds), History of the Church Vol V, London 1980, 418. Murray beklemtoon die belangrikheid van die Geneva Bible waarin baie van Knox se idees opgeneem is. Hierdie uitgawe is byna in elke puritein se huis gelees (Murray, $a w, 7$ ).

61 A L Drummond, The kirk and the continent, Edinburgh 1956, 6. MacLeod, a $w, 34$ noem Knox "one of the Puritan leaders". Lloyd-Jones, $a w, 260-281$ tipeer Knox as "the founder of Puritanism".

62 Kirk, Records of the Scottish Church History Society 18(1974), 176.

63 J Ridley, John Knox, Oxford 1968, 198.

64 Kirk, Records of the Scottish Church History Society 18(1974), 177.

65 Ainslie, Records of the Scottish Church History Society 8(1944), 92; The Scottish Christian Herald, 2/7/1836, 290 \& 25/11/1837, 752.

66 In Skotland het die koningshuis dikwels gepoog om die episkopaalse model op die Skotse kerk af te dwing. F MacLean, $A$ concise history of Scotland, London 21983, 185.

67 R B Knox, "Puritanism past and present", Scottish Journal of Theology 19(1966), 296; Murray, $a w, 3$.

68 H Algra, Het wonder van de negentiende eeuw. Van vrije kerken en kleine luyden, Franeker [1965], 20-21; Van Schelven, $a$ w, 168-169.

69 Van Schelven, $a w, 170$.

70 Sprunger, $a w, 460$. Ryken bespreek verskeie tekortkominge van die puriteine uitvoerig. Hy noem onder andere: "An inadequate view of recreation", "Too many rules", "Too many words", "Too much pious moralizing", "Male Chauvinism", "Insensitivity to the religious feelings of other groups" en "Puritan Extremism". Ryken, $a$ w, 189-201.

$71 \quad$ Flynn, $a w, 88-89$.

72 K L Sprunger, "English and Dutch sabbatarianism and the development of Puritan social theology (1600-1660)", Church History 51(1982), 24.

73 Sprunger, Church History 51(1982), 25. Vergelyk 30-31; A L Drummond, "Scotland and New England in church history: A parallel and a contrast", Records of the Scottish Church History Sociery 7(1941), 90-91. 
74 Sprunger, Church History 51(1982), 25.

75 Sprunger, Church History 51(1982), 26-27.

76 E Pinnington, "Glimpses of old Scots parish life", Scottish Historical Review 4(1907), 63-72.

77 R D Brackenridge, "The enforcement of sunday observance in postrevolution Scotland 1689-1733", Records of the Scottish Church History Society 17(1972), 33. In hierdie artikel wou Brackenridge bewys dat die algemene opvatting van die Skotse Sondag as 'n "strictly-enforced and stringentlyobserved Sabbath" nie korrek is nie, maar dat dit eerder op foutiewe en ongesubstansieerde veralgemenings gebaseer is. Vergelyk Provand, $a w, 178$.

78 D Y Cameron, A Scotsman's heritage, London 1932, 187.

79 L Praamsma, De Kerk van alle tijden Vol 2, Franeker 1980, 156.

$80 \quad$ Flynn, $a w, 91$.

81 Provand, $a w, 79-80$.

82 J B Torrance, "Covenant or Contract?", Scottish Journal of Theology 23(1970), 71-73; Provand, a $w, 207-210$.

83 Cameron, $a w, 35$.

84 Kerkraadsnotules.

85 G D Henderson, The claims of the church of Scotland, Warwick 1951, 175.

86 Henderson, $a w, 1951,177$.

87 A I C Heron (ed), The Westminster Confession in the church today. Papers prepared for the Church of Scotland panel of doctrine, Edinburgh 31986, 131.

$88 \quad$ Provand, $a w, 54$.

89 G Yule, "Continental patterns and the reformation in England and Scotland", Scottish Journal of Theology 22(1970), 317.

90 Provand, $a w, 80-81$.

91 Provand, $a w, 80-81$.

$92 \quad$ Walker, $a w, 498$.

$93 \quad$ Kuiper, $a w, 216$; MacLean, $a w, 89$.

94 Kuiper, $a$ w, 217; C L Warr, The Presbyterian tradition. A Scottish layman's handbook, London 1933, 266-267. 
95 R D Kernohan, Our church. A guide to the Church of Scotland, Edinburgh $1985,17$.

96 Die presbiteriaanse puriteine was die meerderheidsparty in die Engelse parlement. Heron (ed), $a w, 13$.

$97 \quad$ Henderson, $a w, 1951,49$.

98 J D Douglas, Light in the north. The story of the Scottish covenanters, Grand Rapids 1964, 192.

99 Torrance, Calvin and puritanism, $265 \mathrm{n} 2$.

100 T Steel, Scotland's Story, London 1985, 117-118.

101 Heron (ed), $a w, 48-49$. Kirk tipeer Knox as voorloper van Robert Rollock in die covenant-teologie. Kirk, Records of the Scottish Church History Society 18(1974), 158.

102 M C Bell, Calvin and Scottish theology. The doctrine of assurance, Edinburgh 1985, 53.

103 Bell, aw, 57.

104 Vir meer besonderhede vergelyk Bell, $a w, 58-104$.

105 Torrance, Scottish Journal of Theology 23(1970), 62.

106 MacLeod, $a w, 85$; Drummond, $a w, 108-109,129,136,140$; Henderson, $a w$, 1951, 50; Torrance, Scottish Journal of Theology 23(1970), 64.

107 J H S Burleigh, A church history of Scotland, London ${ }^{3} 1973,225$.

108 Heron (ed), $a w, 13$.

109 J R Glover, The story of Scotland, London 21970 a w, 149.

110 Heron (ed), $a w, 14,16$; F L Cross (ed), The Oxford Dictionary of the Christian Church, London ${ }^{3} 1961,1451$.

111 Heron (ed), $a w, 15 ;$ Burleigh, $a w, 226$.

112 Heron (ed), $a w, 15-16$; MacLean, $a w, 128$.

113 Heron (ed), a $w, 16$.

114 Torrance, Calvin and puritanism, 265.

115 Heron (ed), $a w, 48-49$.

116 Henderson, $a w, 1939,71-72$.

117 R T Kendall, Calvin and English Calvinism to 1649, Oxford 1979, 210. 
Alhoewel dié publikasie op oorspronklike navorsing gebaseer is en baie meriete het, fouteer Kendall myns insiens in sekere van sy a-prioris. 'n Goeie voorbeeld is sy stelling: "Had not Christ died for all, we could have no assurance that our sins have been expiated in God's sight." $A w, 14$. Kendall beklemtoon hier dat geloofsekerheid slegs moontlik is, indien Christus vir almal (universal atonement) gesterf het. Om sy argument dat die puriteinse teologie van Calvyn afgewyk het, verder te versterk, polariseer Kendall Beza en Calvyn. Syns insiens sou Calvyn universal atonement voorgestaan het, terwyl Beza limited atonement as die skriftuurlike gesteun het. Vergelyk $a w$, 13-38. Dit is interessant dat Kendall ook die Heidelbergse Kategismus as 'n eksponent van die verbondsteologie sien en derhalwe nader aan Beza en Westminster as aan Calvyn. Vergelyk $a w, 38-41,210$. Douglas Murray ondersteun die standpunt van Kendall C Heron (ed), $a w, 119$. R Letham, Theodore Beza: "A reassessment" voel daarenteen, dat "Kendall's construction of Theodore Beza's doctrine of faith and assurance is in need of considerable revision. The proposal that he diverged so markedly from Calvin is insupportable," Scottish Joumal of Theology 40(1987), 38. Peterson konkludeer tereg dat dit onregverdig is om Calvyn aan limited of universal atonement te verbind, aangesien Calvyn hom nie eksplisiet oor die aangeleentheid uitgelaat het nie. "Hence the question of Calvin's view of the extent of the atonement is anachronistic." (Cf R A Peterson, Calvin's Doctrine of the Atonement, Phillipsburg 1983, 90).

118 Kendall, $a$ w, 211.

119 Kendall, $a w, 212$. Vergelyk M C Bell ('n dissipel van Kendall) se proefskrif, Saving faith and assurance of salvation in the teaching of John Calvin and Scottish theology (Ongepubliseerde Ph D-proefskrif, Aberdeen 1982), 361369; George Tuttle maak dieselfde geluide as Kendall. G M Tuttle, So rich a soil. John McLeod Campbell on christian atonement, Edinburgh 1986, 21-32.

120 Heron (ed), $a w, 40-53$; Torrance, Calvin and puritanism, 265; Yule, Scottish Journal of Theology 22(1970), 321-322; J B Torrance, "The contribution of McLeod Campbell to Scottish theology", Scottish Journal of Theology 26(1973), 295-311.

121 Yule, Scottish Joumal of Theology 22(1970), 321-322.

122 Ferguson \& Wright (eds), $a w, 550$. Helm toon duidelik aan dat Kendall se siening betwisbaar is. Volgens hom is die verskille tussen die verbondsteologie en Calvyn glad nie so ingrypend as wat Kendall beweer nie. (Cf P Helm, Calvin and the Calvinists, Edinburgh 1982, 80-81).

123 Helm, $a w, 81$. Vergelyk B J van der Walt, "Was Calvin a Calvinist or was/is Calvinism Calvinistic?", Our reformational tradition. A rich heritage and lasting vocation, Potchefstroom 1984, 373-374; Murray, $a$ w, 87. Lake se opinie is dat die puriteinse teologie soms verkeerd verstaan word, aangesien hulle dogmatiese voorveronderstellings losgemaak word van hulle uitlewing daarvan - "This is a serious omission since the internal spiritual dynamic of puritan religion can hardly be understood if the formal doctrinal 
underpinning of that position is discussed in isolation." Lake, $a w, 116$; Vergelyk ook 167. Lake verwerp die siening dat die puriteine hulle geloofsekerheid op 'n subjektiewe selfondersoek gebou het. Volgens hom het die puriteine eerlik geworstel met die vraag: hoe weet ek dat ek uitverkies is? Hulle wou die gaping tussen die objektiewe waarheid dat God uitverkies het en die subjektiewe ervaring daarvan oorbrug - "This was done by a subtle shift of perspective from the objective basis provided by the doctrine of predestination to the situation of the individual believer confronted by the knowledge that some men were elect and others reprobate and yet denied an answer to the key question of his own status", $a w, 156$. Lake kritiseer dus Kendall se analise van die puriteinse teologie implisiet.

124 P Helm, "Calvin, English Calvinism and the logic of doctrinal development", Scottish Journal of Theology 34(1981), 185.

125 Bell verwerf sy doktorsgraad onder die leiding van J B Torrance. Dit verklaar moontlik die ooreenkoms in denke.

126 Bell, a w, 13-18; M C Bell, "Was Calvin a Calvinist?" Scottish Journal of Theology 36(1983), 535-540; M C Bell, "Calvin and the extent of the atonement", The Evangelical Quarterly, 55(1983), 115-123; M C Bell, Saving faith and assurance of salvation in the teaching of John Calvin and Scottish Theology (Ongepubliseerde Ph D-proefskrif, Aberdeen 1982), 361-369; Torrance, Calvin and puritanism, 275; Heron (ed), a w, 45-53; Torrance, Scottish Jourmal of Theology 23(1970), 68; J B Torrance, "The incarnation and 'limited atonement"', The Evangelical Quarterly 55(1983), 83-94.

127 Heron (ed), $a w, 48$.

128 Torrance, Calvin and puritanism, 266-270.

129 Torrance, Scottish Joumal of Theology 23(1970), 69.

130 Henderson, $a w, 1951,49$.

131 Torrance, Scottish Joumal of Theology 23(1970), 69.

132 Torrance, Scottish Journal of Theology 23(1970), 69. Vergelyk Bell, aw, 198.

133 Die plaaslike kerkraad het streng beheer uitgeoefen oor wie wel die sakrament waardig was. So het daar 'n praktyk ontstaan waar die waardiges voor die nagmaal 'n token (toegangskaartjie!) ontvang het. Slegs hulle is tot die tafel toegelaat. J W Claasen, Die kerklik-godsdienstige agtergrond en invloed van die eerste Skotse leraars in Suid-Afrika (Ongepubliseerde D Dproefskrif, Pretoria 1990), 103-104.

134 Torrance, Scottish Journal of Theology 23(1970), 68-69. Vergelyk Heron (ed), $a w, 47-48$.

135 Torrance, Calvin and puritanism, 276. 
136 Kirk, Records of the Scottish Church History Society 18(1974), 158-159.

137 Douglas, $a$ w, 191.

138 H MacPherson, The covenanters under persecution, s $\mathrm{p}$ 1924, 145.

139 Provand, $a w, 182$.

140 Provand, $a w, 183$.

141 Torrance, Scottish Joumal of Theology 23(1970), 67.

142 Bell, $a w, 58$.

143 Vir meer besonderhede oor 'n Skotse gelowige se stryd om geloofsekerheid, vergelyk J E Marshall, "Rabbi' Duncan and the problem of assurance", The Banner of Truth 201(1980), 16-27 \& 202(1980), 24-30.

144 Torrance, Scottish Journal of Theology 23(1970), 66.

145 Claasen, $a w, 420-422$. 